\title{
Inventing Anchors? Aetiological Thinking in Greek and Roman Antiquity
}

\author{
Antje Wessels and Jacqueline Klooster
}

"Why is it that...?" At first sight, aetiologies pursue a universal aim: to gratify the human desire to understand the origin of a phenomenon. In drawing causal connections, aetiologies establish a temporal continuity between the present and the past: they link an object or event to its (proposed) origin. The functions and techniques of aetiologies, however, vary greatly. As our volume demonstrates, aetiologies do not exclusively explore origins, but are also concerned with the future. And while they present themselves as pure descriptions, they often tend to shape the past. They do so, for example, in order to anchor or legitimize a proposed project, vision or agenda in an appropriate authority (the proposed 'origin'). Yet, what is the point of searching for origins and why are aetiological stories employed as a specific technique to prepare - and sell - the future? What exactly are the functions and techniques of aetiologies?

Earlier volumes on the topic of aetiology have shown a marked emphasis on two eras, the Hellenistic period and Augustan Rome. This evidently raises the question why some eras are so fruitful in generating aetiological stories. An explanation can be sought in the specific political and socio-cultural circumstances obtaining at the time. We may think here, for instance, of the need to legitimize novel forms of power in new seats of empire, which are contested, insecure, or not invested with a traditional authority, and therefore have to be anchored in the past. The story, or rather manifold stories, about the origins of Rome, for example, are not the result of free-floating antiquarian exercises; rather, they represent or reflect political, religious, and ideological struggles and negotiations. Likewise, the Aitia of Callimachus, far from being a sterile demonstration of erudition, can be interpreted as an attempt to create cultural cohesion in the Hellenistic world and to work towards the establishment and celebration of Ptolemaic power.

As these examples illustrate, aetiological stories are extremely popular in periods of crisis and change. It is not without reason that in former research on 
'aetiology', e.g. the splendid volumes by Martine Chassignet (2008: Létiologie dans la pensée antique) and Christiane Reitz and Anke Walter (2014: Von Ursachen sprechen. Eine aitiologische Spurensuche - Telling origins. On the lookout for aetiology), and the recent monograph on the uses of time in aetiological narratives by Anke Walter (2020: Time in Ancient Stories of Origin), we find a focus on authors, such as Callimachus (Aetia) or Ovid (Fasti), who were writing during periods of transition. Our volume aims to complement and expand this approach by including further periods, such as the cultural revolution at the beginning of Roman literature (third century ВСЕ) or the establishment of new authority for popes and royals in the Renaissance. In addition, it explores 'aetiology' not only as a form of narrative but also as a tool for thinking.

Distinct from its medical connotation, where aetiology is basically understood as diagnostics (finding a cause for a medical condition to enable eventual healing and recovery), aetiological stories in literature, politics, or religion, rather show a strong emphasis on the effect and are typically employed to introduce something. Apparently there is a close connection between aetiology and innovation. The question is: why?

To gain better insight into this connection, we start from two assumptions: (a) Unlike the 'new', an innovation doesn't come 'out of the blue'. Rather, it is partly new and partly old; in any case it is partly in line with existing or traditional thoughts, concepts, and ideas, while at the same time opening new perspectives. (b) Unlike the new, an innovation must include some elements which are familiar to its recipients. It will only be successful if familiar aspects are successfully communicated to them. As a consequence, if there is too little in the past (or even nothing) to which a project could be linked, then these elements have ex post to be constructed - for example, if not enough familiar elements exist (or none at all), if there is no common ground to be addressed (in the sense of a cluster of concepts that the proposed recipients can recognize and understand) or if there is no authority that could legitimize the project. Aetiological thinking in fact often creates such a link to an appropriate 'origin', in order to convince the recipients that the proposed innovation is in line with its tradition or with what it aims to present as its 'tradition'. 


\section{Discontinuity is Translated into Continuity}

Aetiologies aim at creating continuity. They are less concerned with 'roots' than with the 'routes': the continuity between an alleged origin and its desired result, be it the introduction of a ritual, an institution or political program, or the innovation of a literary genre. Analogous to etymological explanations (for example, the etymologies provided by Varro or discussed in Isidore of Seville's Etymologiarum sive originum), aetiologies present the 'origin' (e.g. a historical or legendary event) not as an explanandum, but as explanans, as an agent which, at a later stage, would turn out to have unfolded its potential or will unfold it in the desired future.

As a result, aetiological stories show the tendency to ignore alternative traditions which would interfere with the proposed linearity between the object to be explained and its origin. Ambiguities, pluralism, and diversity are reduced; alternative models are excluded; discontinuities are translated into a model of continuity. For example, when in the third century BCE Romans claim that their dramatic productions are in line with the tradition of Greek literature and culture, alternative origins of Roman theater, such as indigenous Italic traditions, are simply cut off. A methodologically similar approach can be found in the Philhellenic projects of the first century BCE (e.g. Cicero), and again, in early modern times and 18th-century-Philhellenism (e.g. Winckelmann).

\section{Single Origin - Multiple Origins - No Origin?}

Aetiologies are often in search of one single origin, striving for unambiguous connections. Yet, an absence of ambiguity is not a universal feature of aetiologies. A rather different approach to dealing with multiple traditions and, as a consequence, with a diversity of expectations and common grounds is to provide multiple explanations for a single event or fact and to exhibit this variety explicitly. In the case of multiple explanations (Mehrfacherklärungen) none of the alternative explanations is privileged, let alone considered to be exclusive; nor are they meant to display an author's uncertainty. The variety of possible explanations is rather explicitly highlighted and showcased in order to demonstrate the author's erudition or philosophical agility. Mehrfacherklärungen aim to demonstrate the variety and ambiguities of the tradition, and the multiple ways of assessing that tradition. In Plutarch's Greek and Roman Questions, for example (a text discussed by Michiel Meeusen in the present volume), we frequently find several explanations for obsolete 
or incomprehensible cult rituals. Plutarch is inclined to present various approaches for discerning their origins: historical explanations are juxtaposed with mythical ones or even plainly allegorical ones. While Plutarch appears to be seriously interested in exploring origins, he indicates at the same time that there are multiple ways of seeing and approaching the world. How we arrive at an interpretation depends largely on our 'discipline' (or 'theoretical' framework).

Finally, we find approaches which are sceptical that any foundational act can explain the origin of a phenomenon (e.g. a religion or a city). Paradoxically, while these approaches present the origin itself as contested (as discussed in Susanne Gödde's contribution to our volume), at the same time, they ostensibly refer to it. While responding to the need of ascertaining an origin, there is also an increasing awareness - already in antiquity - of the instability of aetiological stories and the (partly) fictional character of their content.

\section{The Paradoxical Structure of Aetiological Thinking}

Aetiologies essentially display a paradoxical structure. They pave the way for progress and innovation by casting an anchor into the past and they prepare their audiences for open-mindedness by explaining the past as well as reducing complex ambivalence and plurality to plainly causal and temporal relations. There is one further aspect to be mentioned: aetiology also displays a paradoxical conception of time. An aetiological story unfolds chronologically, from the past to the present with an indication of the future, adhering to the order of cause and effect, beginning with the origin and ending with the effected result. The thinking upon which these aetiological stories are based, however, displays a completely different 'chronology'. In aetiological thinking, the 'origin' is not at the beginning, but rather at the end of the process. Indeed, this mode of thinking puts it all the other way around. Whereas the stories it produces are perfectly in line with our ideas of chronology - the past precedes the present, and the present the future -, aetiological thinking starts from the end in order to result in a 'description' of the past. To put it most pointedly: the effect is the cause of the cause.

Certainly, modern scholars are well aware that the 'past' is always (re-) constructed from a later perspective and that there is no such thing as the 'truth'. Aetiological thinking, however, brings this perception to a head. It doesn't recoil from intentionally shaping or creating an appropriate past, even when, at the same time, it presents its (fictional) results as true causes or authoritative legitimations. 
is based on a conference held on $16-18$ November 2016 at the University of Leiden. During our conference two major aspects emerged:

First, as indicated above, there is a close connection between aetiology and innovation. An aetiological narrative doesn't build on previous events, rather, it casts an anchor into the vast sea of the past to select and identify an origin deliberately. In this sense, aetiology aims at transforming discontinuity into a model of continuity, while also conflating or even inverting cause and effect. As Jacqueline Klooster argues in her contribution to this volume, this procedure is remarkably discernible in discourses of empire and dynastic rule, such as that of the Ptolemies in the Hellenistic period. The Ptolemies, who originally come from Macedonia but now rule Egypt, incorporate aetiological stories in ex eventu prophecies in court poetry so as to imply that their presence in North Africa is in fact divinely ordained, that they were always meant to be exactly where they are now. Here, aetiological narratives and aetiological thinking exhibit a paradoxical approach to the relation between cause and effect and hence also to 'chronology'.

Second, aetiological thinking - as a tool - goes beyond the human desire to learn something or to legitimize a proposed project; it also has essential aspects.

As we shall see in this volume, techniques of aetiological thinking are mainly employed during periods of fear, threat, and danger. Aetiological thinking helps to explain and explicate what could not be understood otherwise. It helps to structure an indefinite and thereby potentially threatening environment by defining distinct elements and assigning these elements to specific causal agents. Once a 'cause' has been determined, it is possible to exert control and influence. An individual who is subjected to a fearful environment now turns into an agent in his own right who, potentially, is able to act in and control his environment, even if only in words. From an anthropological point of view, aetiological thinking is thus a mental technique which helps to overcome fear. It allows for the articulation or organization of the indefinite or unknown world by providing definite, knowable explanations and thus creating a mental space between this unknown world and the human mind.

According to cognitive theories that have been developed since the 16th century, the ways of understanding and approaching the world can be considered as an evolutionary process. Whereas early stages of the mind, such as magical thinking, don't succeed in providing systematic explanations, logical thinking allows understanding of the causal principle behind an object or phenomenon. If we accept such an evolutionary approach to the human mind 
where logic is preceded by magic, aetiological thinking would be somewhere in between. It is a first step towards logical thinking, for it searches for reasons and recognizes the difference between a cause and its effect. Yet, at the same time, it is still guided by specific teleological interests and happy to establish the (wrong) connections which would support them.

A rather optimistic classification of aetiological thinking along these lines is given by Hermann Gunkel in his Genesis:

Das Kind sieht mit grossen Augen in die Welt und fragt: warum? Die Antwort, die es sich selbst giebt, und mit der es sich bald beruhigt, ist vielleicht sehr kindlich, also sehr unrichtig, und doch, wenn es ein gemütvolles Kind ist, fesselnd und rührend auch für den Erwachsenen. Solche Fragen wirft auch ein antikes Volk auf und beantwortet sie, so gut es kann.... Was wir hier also vorfinden, sind Anfänge menschlicher Wissenschaft, natürlich nur geringe Anfänge, aber als Anfänge doch uns ehrwürdig. (1901: xi-xii)

The child looks at the world with wide eyes and asks: why? The answer that he gives himself, the answer which soon him calms down, is perhaps very childish and therefore quite incorrect, and yet, if he is a cheerful child, the answer is captivating and touching, even for the adult. Such questions are also raised by an ancient people and answered as best they can.... What we find here are the beginnings of human science, of course only small beginnings, but as beginnings nevertheless respectable.

transl. J. HAMILTON

Gunkel indeed considers aetiologies as a preliminary form of scientific thinking. Aetiologies may provide wrong answers. However, in terms of evolutionary development (of an individual as well as human mankind), they are the first serious attempts to 'grasp' the environment - a first step to overcome human subjection to an undefined world.

Two questions emerge from this assumption: (a) Can we indeed assume a unilinear development of the human mind, i.e., is aetiological thinking superior to former approaches, and does it succeed in actually replacing magical thinking? and (b) Does aetiological thinking help to overcome existing fear, or does fear remain a stimulus when it comes to shaping aetiological stories?

In a more sophisticated approach, at the turn of the 2oth century, the art historian Aby Warburg has pointed out that we must generally be careful with assuming an evolutionary process in which primitive approaches would simply 
be replaced by later, more valid ones. The development of logical thinking, for example, in Warburg's terms the creation of a "Denkraum", remains rather under continual threat of a recourse to magical thinking.

Something similar seems to obtain for aetiological thinking. While indeed displaying a first step towards logical thinking and scientific approaches, it likewise remains under permanent threat of atavistic thinking. Moreover, it is not even free from magical elements and can be dangerous itself. A rather disturbing example is the structure and increased emergence of conspiracy 'theories' in crisis situations. While pretending to employ techniques of ratio and exploring the 'truth', conspiracy theories themselves display features of irrational, magical thinking. They have the tendency to reduce a field of possible reasons to one single origin, and they are resistant to any negotiation or revision. The imperative need to figure out 'who has pulled the strings', will never abate, even if there is external evidence that the proffered causal link is incorrect or that the existence of a specific agent behind the scenes is highly questionable. Thus, whereas aetiological thinking can be helpful, it can also be extremely perilous. Especially when it is employed to promote political purposes, the creation of causal relations can lead to deliberate, ideologically tinged connections. To explore the reasons why aetiological thinking is employed and to investigate to what end aetiological stories are presented, will remain an ongoing challenge - not only for historians, but for everybody and for all times.

This volume presents ten case studies. Nine chapters revolve around ancient aetiological discourse: ancient texts and their techniques of employing (or questioning) aetiology as a tool for thinking. One chapter (Susanna de Beer's chapter) will help to understand how the ancient aetiological discourse is imitated in one of the key eras of its 'Nachleben': when Renaissance Popes, in a context of competition, aimed at turning Rome herself into an anchor in order to promote their own political projects. The volume explores aetiological discourse from three perspectives.

The three chapters collected in Part 1: Aetiological Thinking: Old \& New, From Present to Past to Future, focus on aetiology as a mental and ideological device to structure and legitimize the projected future in Attic tragedy and Hellenistic poetry (contributions by Annette Harder and Jacqueline Klooster). Part 2: Aetiology and Politics, explores the political dimensions of aetiological discourse in periods of change: Roman comedy (Andrea de March), Augustan literature (Alexander Kirichenko) and Renaissance genealogical and dynastic discourses (Susanna de Beer). Finally, Part 3: Aetiology in Myth and Science: From Religion to Research, demonstrates how aetiological thinking marks 
the transition from religious contexts, such as pagan cult ritual (Susanne Gödde) and late antique Hermeticism (Sean McGrath), to rational thinking, as found in Palaephatus's rational explanations of mythology (Hugo Koning), in quasi-scientific parodies in the satirical works of the Imperial Age (Inger Kuin), and in ancient scientific writing (Michiel Meeusen).

\subsection{Part 1: Aetiological Thinking: Old \& New, From Present to Past to Future}

The first part, Aetiological Thinking: Old \& New, From Present to Past to Future, opens with Annette Harder's chapter "Anchoring Innovations through Aetiology." With examples from Pindar, Euripides, Apollonius of Rhodes, Callimachus, Vergil, and Ovid she shows that aetiology is a way of anchoring the present in the past, but also of anchoring innovations for the future in the present, particularly on religious, ideological, and political levels. Harder also analyzes how aetiological stories may be adapted to a new context, where they can be used to establish new institutions that differ or depart from the ones they originally sponsored. As this chapter demonstrates, an important tool in this process is the use of intertextuality.

Next, Jacqueline Klooster explores why Ex eventu-prophecies form such a frequent phenomenon in ancient literature, occurring for example in Pindar's Pythian 4, Euripidean tragedy, and Vergil's Aeneid. In such cases, a god or seer prophesies the future (which equals the present or even past for the intended recipients of the text), and thus lends special authority and confirmation to the course of history, or to the present, often with distinctly political or ideological overtones. Thus, an aetiological story is often wrapped in a prophecy. Starting from these observations, Klooster analyzes the structural similarities between aetiological and prophetic texts.

\subsection{Part 2: Aetiology and Politics}

The second part, Aetiology and Politics, investigates how aetiologies can contribute to the successful performance and introduction of new agendas and how they can help to anchor literary or political innovations and make them more accessible to their proposed audience. In his chapter "Veterem atque antiquam rem novam ad vos proferam," Andrea de March explores how aetiological thinking is addressed in Plautine comedy, a genre which built on a long (also indigenous Italic) tradition, but became successful only after presenting its productions as 'barbarian translations' (i.e., into Latin) of certain Greek models. In his chapter, De March demonstrates that Plautus' meta-literary discourse in fact aims at 'double anchoring' his poetic innovations. At first 
sight, Plautus seems to promote two contradictory statements: he claims to rely on old Greek models and to present 'something new'. Yet, in another regard, these two statements can be seen as complementary parts of one and the same persuasive strategy. Plautus employs aetiological thinking in order to suggest continuity. By being portrayed as deriving from the prestigious Greek literary precedents, his comedies and their new features are legitimized by an authority, which can be considered to be accepted by his audience.

Similar techniques can be seen in Augustan literature, specifically with respect to the reception of Callimachus' Aitia. Here, however, aetiology not only serves as a device to anchor Roman literary innovations in Hellenistic literature. The Roman reception of Callimachus' Aitia first of all includes political dimensions. In his chapter "Callimachus Romanus. Propertius' Love elegy and the Aetiology of Empire," Alexander Kirichenko argues that the way Propertius claims a Callimachean 'origin' for his poetics provides him with an anchor for conceptualising a "conjunction between the elegiac longing for an ever-retreating object and the never-ending imperial expansion of Augustus' empire".

Finally, Susanna de Beer investigates how ancient Rome in the Renaissance has been turned into an anchor in itself. Her chapter "The Origins of Rome in the Renaissance. Revival \& Reinvention, Rejection \& Replacement" presents three different ways of employing the ancient aetiological discourse of Rome's foundation. By discussing a selection of Latin texts that were produced in specific political or religious contexts, De Beer argues that these approaches can be analyzed as competing heritage claims to the Roman past to legitimize different 'presents'. The foundation myths of Rome played a key role in the papal politics of renovatio imperii of the Renaissance. However, this ideology also had its opponents, who tapped into the same aetiological discourse to undermine the papal claims to Rome. They had various techniques to do so: they ridiculed the foundation myths or interpreted them in a completely different way. Others tried to 'prove' the discontinuity between the foundation stories of Rome and the Renaissance city by emphasizing the state of ruin or neglect of its most important sites of origin. Paradoxically, the opponents of the papal renovatio imperii often also advocated a translatio imperii by means of the same aetiological discourse. On the basis of Rome's Trojan origins new foundation myths were invented and adapted to fit new political or religious contexts. Although all these aetiologies essentially create a link between the past and the present, the particular type of link is different: in Rome itself, the discourse focuses on the continuity of place, whereas outside Rome genealogical ties to Rome's origins are emphasized. 


\subsection{Part 3: Aetiology in Myth and Science: From Religion to Research}

Part 3, Aetiology in Myth and Science: From Religion to Research, opens with Susanne Gödde's chapter "Resistance to Origins. Cult Foundation in the Myths of Dionysus, Apollo, and Demeter," which analyses the narrative status of religious foundation myths. Many foundation myths, especially those of cities or cultic institutions, construct origins as circuitous, as the result of a conflict or as a successful struggle against former resistance. Examples include the introduction of the cult of Dionysus into Athens, the foundation of Apollo's oracle in Delphi, and the aetiology of the Eleusinian mysteries. All of these narratives articulate a conspicuous resistance to the arrival and institution of a particular deity. This raises the question why this is the case and what it reveals about how the Greeks conceptualized religious order. Moreover, the well-known foundation myths of Athens and Thebes consider the origins of the respective city as the result of a quarrel, tracing the ideologies of these cities back to an act of violence. The question is highly relevant for our view on 'aetiology': Do we really find a strong and authoritative concept of beginnings in these narratives? Or do they not, rather, avoid claiming a singular starting point or founding act?

In religious contexts, aetiological thinking seems to be the result of a long-term development. As the following chapter suggests, however, it also contributes to a successful Nachleben of religious cults. In his contribution "Beginning with Hermes: Promoting Hermeticism through Aetiology in Corpus Hermeticum 1," Sean E. McGrath examines the cult of Hermes Trismegistus, one of the Hellenistic cults with the longest Nachleben, by exploring the use of aetiological motives in the Poimandres. In a dialogue with the eponymous deity Poimandres, the alleged archaic Egyptian sage Hermes Trismegistus receives a revelation about the creation of the world couched in concepts from (middle) Platonism, especially the cosmogony from the Timaeus and the dualism between the immortal soul and the transient body. The dramatic setting establishes the Egyptian Hermes as the original source of Platonic philosophy, later appropriated by Greek thinkers. Presenting Hermes as a first inventor corresponds to a wider tradition of Greek philosophers who receive Egyptian wisdom. Furthermore, Poimandres' account contains striking similarities with the creation myth in Genesis which serve as an 'anchor' to establish common ground between the Hermetic texts and Jewish readers. The Poimandres, therefore, uses aetiology both as a form of competition with other intellectual and religious traditions and as a technique for appealing to a wider audience.

Apparently, on the one hand, aetiologies help to stimulate the Nachleben of a religious cult. Unlike other cults of similar character, which perished during antiquity, the figure of Hermes reached both the Christian and Islamic world 
in the medieval era and even saw a revival during the Renaissance. On the other hand, the development of aetiological thinking is part of - and contributes to processes of rationalization.

Discourses in which this transition becomes especially clear are the rational explanations of well-known myths, as we find them in Hellenistic literature an aspect which is at the heart of Hugo Koning's chapter on "Aetiology and Rationalizing Mythography." Koning explores the aetiologies which are presented by the Hellenistic mythographer Palaephatus. His rationalizations of some of Greece's best-known myths depend on finding the 'origin' that sparked the tale. According to Palaephatus, the Hydra that Heracles fought, was actually a fortress by that name; Aeolus was no lord of winds but an astronomer; and Medea did not boil people but invented the steam bath instead. By systematically searching for natural and credible origins behind traditional tales, Palaephatus rationalizes myth and supplants a mythical view of early times with an acceptable, modern or 'historical' one. Palaephatus is clearly searching for origins; the way he does so, however, is entirely different from other projects which present aetiological myths. Instead of 'othering' the mythical past, visualizing the long-lost world of myth as a place where gods and heroes perform superhuman feats which have created the world as it is today, Palaephatus strives to normalize the past, erasing all traces of the supernatural, and linking it as close as possible to his present-day experience.

As this example demonstrates, there is a clear transition from myth to rationalization, which also affects the approaches to aetiology. Yet, as pointed out above, this shouldn't suggest that there is a one-directional history of the human mind or that these developments in modes of thinking have been accepted throughout. Already in early Roman literature (e.g. in Ennius' and Pacuvius' tragedies) we find traces of critical attacks on philosophical explanations of myths, and, of course, we find them in later periods as well. A good example of how the rationalization of myths has been criticized via aetiological thinking, is Lucian's De parasito (On the parasite), a text from the second century CE. As Inger Kuin shows in her chapter "Patroclus was a Parasite. Lucian's Satirical Aitia," Lucian's treatise is a clear parody of the genre of encomium, but it also takes aim at the efforts of myth rationalizers, from Prodicus ( 5 th $\mathrm{BCE}$ ) to Heraclitus (2nd $\mathrm{CE}$ ), to explain origin myths, by explaining the origins of origin myths. With his satire Lucian exposes the double bind that troubled myth rationalizers: on the one hand, they want to stay true to their standards of plausibility, on the other hand, they want to salvage the aetiological tradition as much as possible. As a result, many of their 'rational' explanations are scarcely more credible than the mythical aetiologies they were meant to explain in the first place. Lucian's parodies aim to show that 
the rationalizers fail to understand the difference between everyday causality and mythical causality: unlike 'scientific' explanations (e.g., historiographical, medical), aetiological narratives can be 'true' even if they are unlikely. This type of truth can be played with through humor - as Lucian himself does time and again - but trying to apply (proto-)scientific reasoning to myths will make you look like a fool.

Part 3 concludes with a chapter demonstrating that critical views on rationalization and monocausal, linear thinking were not limited to satirical works, but rather also an issue in serious, scientific contexts - albeit with different results. In scientific treatises, such as Plutarch's Aitiai, we find the tendency to assume multiple causes. As Michiel Meeusen points out in his chapter "Crossing Borders: Aetiological Overlaps in Plutarch's Collections of Questions," aetiological research is an important aspect of Plutarchan writing. It plays a significant discursive role throughout the Vitae and the Moralia, and Plutarch composed a significant number of collections of Aitial. One

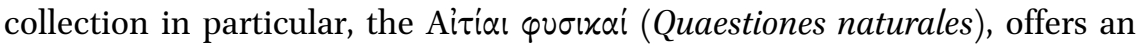
intriguing perspective on Plutarch's causal interest in natural phenomena. Meeusen's chapter examines how the Aitía tie in with Plutarch's aetiological program more generally, that is, which intertextual dynamics can be observed in the work. By providing an analysis of the conceptual overlaps within the oeuvre, Meeusen demonstrates that they reveal the openness and all-round applicability of many kinds of knowledge to different contexts - an intertextual dynamic that lies at the heart of Plutarch's $\pi \circ \lambda \nu \mu \alpha \dot{\theta} \theta \varepsilon ı$ project.

Taking in this overview, we can state that aetiology as a tool for thinking was used not only to overcome primal fears by shaping a 'Denkraum', or to sell (literary and political) innovations and pave the way for logical, plain explanations of the past while planning the future. Importantly, it also re-opens a space for discussion. Plutarch's openminded questions, allowing for multiple possible explanations ( $\pi$ ó $\varepsilon$ pov ...; $\ddot{\eta}$...; $\ddot{\eta}$...;), should be the agenda of scientific research in general, and we hope that this will go for our volume as well. The ten case studies presented here touch upon a number of crucial aspects of aetiological thinking, but, of course, no volume is able (nor claims) to give a final and complete explanation of the phenomenon explored. We have asked "Why Aetiologies?" and have provided several approaches and explanations. It is our hope that the analyses of aetiological narratives in previous research may be complemented and further enlightened by the present volume with its focus on aetiology as a tool for thinking, and that our explorations of the 
topic will help to stimulate further discussions and innovative approaches. Especially in a period of crisis and change such as we are currently witnessing, a critical evaluation of aetiological thinking, its opportunities and risks, remains relevant more than ever.

\section{Our Thanks Go Out to ...}

the Universities of Leiden and Groningen who have funded the Anchoring Innovation Pilot in 2016-2018, before the project turned into the Gravitation Grant in 2017; ${ }^{1}$ to Ineke Sluiter and André Lardinois as the two directors of the project; to all participants and speakers who contributed to the discussions in 2016. Finally, our thanks go out to Irene de Jong and Eric Moormann (series editors), to Mirjam Elbers and Giulia Moriconi (at Brill) for their encouragement and their support, to the anonymous reader who read the whole manuscript and made many helpful suggestions, to Cornelis van Tilburg for preparing the index locorum and to Caroline van den Oever for her editorial work on the chapters.

1 Anchoring Innovation is the Gravitation Grant research agenda of the Dutch National Research School in Classical Studies, OIKOS. It is financially supported by the Dutch ministry of Education, Culture and Science (NWO project number 024.003.012). For more information about the research program and its results, see the website www.anchoringinnova tion.nl. 